НАУКОВИЙ ВІСНИК

Vetsing Ger or Liv National University of

$\pi$

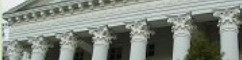

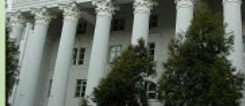

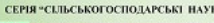

Том 22 № 92 2020
Науковий вісник Дьвівського національного університету ветеринарної медицини та біотехнологій імені С.3. Гжицького. Серія: Сільськогосподарські науки

Scientific Messenger of Lviv National University of Veterinary Medicine and Biotechnologies. Series: Agricultural sciences

UDC 636.598.087.72:612.1

\title{
Changes in goslings' blood pattern under the influence of different doses additives of selenium in forages
}

\author{
S. V. Sobolieva ${ }^{1}$, B. V. Gutyj ${ }^{2}$, O. I. Sobolev ${ }^{3}$ \\ ${ }^{1}$ Bila Tserkva Institute of continuous professional training, Bila Tserkva, Ukraine \\ ${ }^{2}$ Stepan Gzhytskyi National University of Veterinary Medicine and Biotechnologies Lviv, Ukraine \\ ${ }^{3}$ Bila Tserkva National Agrarian University, Bila Tserkva, Ukraine
}

Article info

Received 03.02.2020

Received in revised form 03.03 .2020

Accepted 04.03.2020

Bila Tserkva Institute of continuous professional training.

Levanevskoho, 52/4, Bila Tserkva, 09111, Ukraine.

Tel.: +38-097-172-22-26

E-mail: s0lana@ukr.net

Stepan Gzhytskyi National University of Veterinary Medicine and Biotechologies Lviv,

Pekarska str., 50, Lviv,

79010, Ukraine.

Bila Tserkva National Agrarian University,

Soborna sq., 8/1, Bila Tserkva 09111, Ukraine.
Sobolieva, S. V., Gutyj, B. V., \& Sobolev, O. I. (2020). Changes in goslings' blood pattern under the influence of different doses additives of selenium in forages. Scientific Messenger of Lviv National University of Veterinary Medicine and Biotechnologies. Series: Agricultural sciences, 22(92), 5055. doi: 10.32718/nvlvet-a9209

According to many scientists, the list of trace elements that are currently used in compound feeds for various types of poultry is clearly insufficient. In recent years, applied research has been conducted to determine the physiological needs of poultry for certain mineral elements that perform important biochemical functions in the body. This also applies to such biotic ultramicroelement as selenium. Scientific research of domestic and foreign scientists in the field of physiology, biochemistry, medicine and veterinary medicine has proved that selenium is a trace element with a fairly wide range of physiological and biochemical effects. When developing and theoretically justifying optimal norms for introducing selenium into poultry feed, it is necessary to evaluate not only its productive qualities, but also the blood picture. The question of the influence of selenium on changes in blood parameters in the poultry body is a great theoretical and practical significance because it allows us to expand our knowledge of its biological role and explain the data obtained in experiments. In scientific and economic experience has been studied the influence of additives of different doses of selenium in compound feed on the morphological and biochemical parameters of the goslings' blood raised for meat. During the experiment, feeding of goslings of all groups were carried out with dry feed mixes in accordance with existing norms. The goslings of the first control group did not receive selenium supplementation. The poultry of the second experimental group were additionally fed selenium at the rate of $0.2 \mathrm{mg} / \mathrm{kg}$, the third of 0.3 and the fourth of $0.4 \mathrm{mg} / \mathrm{kg}$. It is established that the additive in the feed of different doses of selenium stimulate hemocytopoiesis are added to different compound feeds, this is achieved by a homogeneous tendency per day, within physiological values in the goslings' peripheral blood number of red blood cells (by 1.7-3.9\%), white blood cells (by 2.1-3.2\%) and hemoglobin (by 2.4-8.6\%). Immune defense mechanisms are activated, which is manifested in an increase in the level of total protein (by 1.4-3.8\%) and the concentration of immunoglobulins in the blood serum (by 3.2 $9.7 \%)$. It is found changes in the content of total glutathione and its reduced form in the blood indicate a positive effect of selenium on the non-enzymatic element of the antioxidant defense system of the poultry's body. The addition of selenium to compound feed at a dose of $0.3 \mathrm{mg} / \mathrm{kg}$ had a significant effect on the morphological and biochemical parameters of the goslings' blood raised for meat.

Key words: goslings, blood, selenium, dose, all-mash.

\section{Зміни в картині крові у молодняку гусей під впливом добавок різних доз Селену в комбікормах}

С. В. Соболєва ${ }^{1}$, Б. В. Гутий${ }^{2}$ О. І. Соболєв ${ }^{3}$

${ }^{1}$ Білочерківський інститут неперервної професійної освіти, м. Біла Церква, Украӥна 
${ }^{2}$ Львівський національний університет ветеринарної медицини та біотехнологій імені С. 3. Гжицького, м. Львів, Україна

${ }^{3}$ Білочерківський національний аграрний університет, м. Біла Церква, Україна

Перелік мікроелементів, які сьогодні використовуються у складі комбікормів для різних видів сільськогосподарської птииі, на думку багатьох учених, явно недостатній. Останніми роками проводяться прикладні дослідження шодо визначенням фізіологічної потреби птиці в деяких мінеральних елементах, які виконують важливі біохімічні функиії в організмі. Це стосується й такого біотичного ультрамікроелементу, як Селен. Наукові дослідження вітчизняних і зарубіжних учених у галузі фізіології, біохімї, медицини та ветеринарії переконливо довели, щяо Селен є мікроелементом з досить широким спектром фізіологічних і біохімічних ефектів. При розробці та теоретичному обтрунтуванні оптимальних норм уведення Селену в комбікорми для птиці варто оцінювати не тільки ї̈ продуктивні якості, а й картину крові. Питання впливу Селену на зміни показників крові в організмі птиці мають важливе теоретичне і практичне значення, тому що дозволяють, розширити наші знання про його біологічну роль та пояснити дані, одержані в експериментах. У науково-господарському досліді вивчено вплив добавок різних доз Селену в комбікорми на морфологічні та біохімічні показники крові гусенят, що вирощуються на м'ясо. Годівля гусенят усіх груп упродовж досліду здійснювалася сухими повнораціонними комбікормами відповідно до існуючих норм. Гусенята першої контрольної групи добавку Селену не одержували. Птиці другої дослідної групи у комбікорми додатково вводили Селен із розрахунку 0,2 мг/кг, третьої-0,3 та четвертої - 0,4 мг/кг. Встановлено, щчо добавки в комбікорми різних доз Селену стимулюють гемоцитопоез, про ие свідчить одночасна тенденція до підвищення, в межах фізіологічних величин, у периферичній крові молодняку гусей кількості еритроцитів (на 1,7-3,9 \%), лейкоцитів (на 2,1-3,2 \%) та вмісту гемоглобіну (на 2,4-8,6 \%). Активуються механізми імунного захисту, шо проявляється у підвищенні рівня загального білка (на 1,4-3,8\%) та концентращіі імуноглобулінів у сироватці крові (на 3,2-9,7 \%). Виявлені в крові зміни вмісту загального глутатіону та його відновленої форми засвідчують позитивний вплив Селену на неферментативну ланку антиоксидантної системи захисту організму птиці. Добавка Селену в комбікорми у дозі 0,3 мг/кг справила суттєвий вплив на морфологічні та біохімічні показники крові гусенят, щзо вирощуються на м'ясо.

Ключові слова: гусенята, кров, Селен, доза, комбікорм.

\section{Вступ}

М'ясне птахівництво є найбільш динамічною галуззю аграрного сектора економіки, здатною у найближчі роки докорінно поліпшити забезпечення населення світу високоякісними дієтичними продуктами харчування та зміцнити продовольчу безпеку багатьох держав. Світовий сектор птахівництва має щорічну стійку тенденцію до зростання, оскільки попит на його продукцію обумовлений збільшенням чисельності населення, ростом доходів та урбанізацією. Подальший розвиток птахівництва може призвести до відкриття нових робочих місць у технологічно пов'язаних суміжних галузях, зокрема комбікормовій, переробній та харчовій i, як наслідок, сприятиме частковому вирішенню проблеми безробіття у світі (Vijayakumar \& Damodaran, 2015; Mottet \& Tempio, 2017; Wahyono \& Utami, 2018).

Питання, пов'язані 3 підвищенням продуктивних якостей птиці та зниженням собівартості одиниці продукції, були і залишаються актуальними. У вирішенні цих завдання важлива роль відводиться повноцінній годівлі птиці, зокрема забезпеченню їі потреб в yсіх поживних і біологічно активних елементах живлення, у тому числі й макро- і мікроелементах.

Сьогодні значно зросло число показників, за якими контролюється мінеральне живлення сільськогосподарської птиці. Фізіологічна потреба в деяких мінеральних елементах, що виконують важливі біохімічні функції в організмі, ще остаточно не встановлена. Не визначена й оптимальна норма введення в комбікорми для різних видів і технологічних груп сільськогосподарської птиці такого біотичного елементу, як Селен.

Наукові дослідження вітчизняних і зарубіжних учених у галузі фізіології, біохімії, медицини та ветеринарії переконливо довели, що Селен є мікроелементом 3 досить широким спектром фізіологічних і біохімічних ефектів.
Незважаючи на малі концентрації в організмі, Селен виконує унікальні багатопланові функції каталітичну, структурну, регуляторну, в процесі здійснення яких він активує дію багатьох ферментів, вітамінів, гормонів, і цим забезпечується нормальне функціонування різних біологічних систем, здійснення численних фізіолого-біохімічних реакцій в живому організмі (Sobolev et. al., 2018).

Біохімічні функції Селену визначаються не самим мікроелементом, а селенопротеїнами, що містять селеноцистеїновий залишок як невід'ємну частину їхнього активного центру. На сьогодні виділено та ідентифіковано в чистому вигляді понад 30 таких специфічних селенопротеїнів, але відома біологічна роль тільки 15 із них (Rocha et al., 2017).

Беручи участь в складному комплексі ферментних систем Селен і його з'єднання істотно впливають на окислювально-відновні процеси, обмін речовин і енергії в організмі на біологічному, хімічному і молекулярному рівнях. На сьогодні встановлено, що Селен володіє антиканцерогенними (Wallenberg et al., 2014), антиоксидантними (Ramoutar \& Brumaghim, 2010), радіопротекторними (Graupner et al., 2016), імуностимулюючими (Shirsat et al., 2016), антивірусними (Shojadoost et al., 2019) та антитоксичними (Chena et al., 2014; Bjorklund, 2015) властивостями. Існують докази впливу Селену на остеогенез (Zeng et al., 2013) та відтворювальну функцію тварин і птиці (Ahangari et al., 2013; Tsuneda et al., 2019).

Відкриття біологічних властивостей та розкриття біохімічних механізмів дії Селену стало підставою для використання його у ветеринарній та зоотехнічній практиці. У ветеринарії препарати Селену з успіхом використовуються для лікування та профілактики різних захворювань тварин і птиці, зокрема ексудативного діатезу, м'язової дистрофії, перозису, енцефаломаляції, анемії, фіброзу підшлункової залози, мікропатії м'язового шлунка та серця, жирової дегенерації, дистрофії печінки та інших. 
У зоотехнії, зокрема у м'ясному птахівництві, Селен стали використовувати порівняно недавно. Сполуки Селену вводять до складу комбікормів для різних видів сільськогосподарської птиці 3 метою підвищення їхньої живої маси, життєздатності, конверсії корму, забійних і м'ясних якостей, органолептичних показників м'яса, його амінокислотного складу, харчової та біологічної цінності (Sobolev, 2010; Surai, 2018).

Як видно $з$ викладеного вище, вже перші спроби використання Селену в зоотехнічній практиці дозволили одержати результати, які доводять безумовну необхідність визначення оптимальних диференційованих норм уведення його в комбікорми для сільськогосподарської птиці різного виду, віку і напряму продуктивності.

При розробці та теоретичному обгрунтуванні оптимальних норм уведення Селену в комбікорми для птиці варто оцінювати не тільки ії продуктивні якості, а й картину крові, оскільки вона найоб'єктивніше характеризує внутрішнє середовище, у якому відбуваються всі важливі процеси життєдіяльності організму. Питання впливу Селену на зміни показників крові в організмі птиці мають важливе теоретичне i практичне значення, тому що дозволяють, по-перше, розширити наші знання про його біологічну роль, а по-друге - пояснити дані, одержані в експериментах.

Мета дослідження. Дослідити вплив добавок різних доз Селену в комбікормах на морфологічні та біохімічні показники крові гусенят, що вирощуються на м'ясо.

Матеріал і методи дослідження. Експериментальні дослідження проводилися на чистопорідних гусенятах горковської породи. Для проведення науковогосподарського досліду було відібрано 400 голів добових гусенят, не розділених за статтю, з яких, за принципом аналогів, сформували чотири групи (по 100 голів у кожній). Тривалість науковогосподарського досліду відповідала періоду вирощування гусенят на м'ясо і становила 75 дні.

Гусенятам контрольної та дослідних груп упродовж періоду вирощування згодовували розсипні повнораціонні комбікорми, збалансовані за основними поживними та біологічно активними речовинами. Водночас молодняку дослідних груп в комбікорми додатково вводили різну кількість Селену у формі натрію селеністокислого $\left(\mathrm{Na}_{2} \mathrm{SeO}_{3}\right)$, згідно зі схемою науково-господарського досліду (табл. 1).

\section{Таблиця 1}

Схема науково-господарського досліду на гусенятах

\begin{tabular}{lcc}
\hline \multicolumn{1}{c}{ Група } & Кількість птиці у групі, гол. & Добавка в комбікорми селену, мг/кг \\
\hline 1 контрольна & 100 & $\mathrm{OP}^{*}$ \\
2 дослідна & 100 & $\mathrm{OP}+0,2$ \\
3 дослідна & 100 & $\mathrm{OP}+0,3$ \\
4 дослідна & 100 & $\mathrm{OP}+0,4$ \\
\hline Примітка: ${ }^{*} \mathrm{OP}$ - основний раціон (повнораціонний комбікорм) &
\end{tabular}

Гусенята вирощувалися на підлозі на незмінній підстилці, $з$ дотриманням параметрів щільності посадки, освітлення та мікроклімату відповідно до технології, що використовується на птахопідприємстві.

По закінченню науково-господарського досліду, 3 метою вивчення механізмів опосередкованого впливу різних доз Селену на регуляцію фізіологічних і біохімічних процесів в організмі, були відібрані проби крові у гусенят контрольної та дослідних груп (по 5 голів 3 кожної). Кров у гусенят отримували до ранкової годівлі з підкрилової вени. Відібрані проби цільної крові ділили на дві частини: одну - стабілізували антикоагулянтом (5 \% розчином натрію гідроцитрату), другу - використовували для одержання сироватки крові.

При дослідженні показників крові використовували такі методи:

- формені елементи крові - меланжерним методом;

- гемоглобін - геміглобінціанідним методом;

- загальний білок у сироватці крові - рефрактометричним методом;

- загальну кількість імуноглобулінів у сироватці крові - фотоелектроколориметричним методом;

- загальний глутатіон та його форми - йодометричним методом.
Отриманий цифровий матеріал опрацьовували методами варіаційної статистики на персональному комп'ютері 3 використанням програми Microsoft Excel. Різницю між групами оцінювали за критерієм Стьюдента i вважали вірогідною при значеннях: ${ }^{*}-\mathrm{P}<0,05 ;^{* *}-\mathrm{P}<0,01$.

Результати дослідження та обговорення. Життездатність i продуктивність птиці безпосередньо пов'язана з різними функціями крові. Кров - універсальна тканинна система, що здійснює зв'язок окремих органів і тканин між собою, а також із зовнішнім середовищем. Численні процеси, що відбуваються в організмі високопродуктивної птиці, насамперед супроводжуються певними змінами складу крові.

Інтенсивний ріст молодняку птиці пов'язаний зі значним фізіологічним напруженням організму, що потребує високого рівня обміну речовин, передусім забезпеченості крові форменими елементами. Результати досліджень, наведені у таблиці 2, показують, що у гусенят другої дослідної групи кількість еритроцитів і вміст гемоглобіну в крові були вірогідно вищими $(\mathrm{P}<0,05)$ на 3,9 та 6,4 \% відповідно - порівняно 3 молодняком контрольної групи, у якого ці показники становили 3,54 Т/л та 133,6 г/л відповідно. 
Таблиця 2

Морфологічні та біохімічні показники крові гусенят, що вирощуються на м’ясо, $\left(\bar{X} \pm S_{\bar{X}}, \mathrm{n}=5\right)$

\begin{tabular}{|c|c|c|c|c|}
\hline \multirow{2}{*}{ Показник } & \multicolumn{4}{|c|}{ Група } \\
\hline & 1 контрольна & 2 дослідна & 3 дослідна & 4 дослідна \\
\hline Еритроцити, Т/л & $3,54 \pm 0,051$ & $3,68 \pm 0,038^{*}$ & $3,63 \pm 0,089$ & $3,60 \pm 0,097$ \\
\hline Лейкоцити, Г/л & $23,62 \pm 1,117$ & $24,12 \pm 1,005$ & $24,16 \pm 0,408$ & $24,37 \pm 0,725$ \\
\hline Гемоглобін, г/л & $133,6 \pm 2,76$ & $142,2 \pm 2,36^{*}$ & $145,1 \pm 3,84^{*}$ & $136,8 \pm 4,58$ \\
\hline \multicolumn{5}{|c|}{ Вміст гемоглобіну в одному еритро- } \\
\hline циті, пг & $37,7 \pm 0,80$ & $38,6 \pm 0,72$ & $40,0 \pm 1,36$ & $38,1 \pm 1,09$ \\
\hline Загальний білок, г/л & $49,4 \pm 1,50$ & $51,3 \pm 1,93$ & $50,4 \pm 0,83$ & $50,1 \pm 1,02$ \\
\hline Імуноглобуліни, г/л & $12,4 \pm 0,40$ & $13,6 \pm 0,53$ & $13,0 \pm 0,59$ & $12,8 \pm 0,38$ \\
\hline \multicolumn{5}{|l|}{ Глутатіон, мг/100 мл: } \\
\hline загальний & $64,5 \pm 0,70$ & $67,8 \pm 1,10^{*}$ & $68,9 \pm 0,87^{* *}$ & $68,7 \pm 1,10^{*}$ \\
\hline відновлений & $53,5 \pm 0,88$ & $57,2 \pm 1,33^{*}$ & $58,0 \pm 1,13^{*}$ & $56,0 \pm 0,72$ \\
\hline окиснений & $11,0 \pm 0,31$ & $10,7 \pm 0,46$ & $10,9 \pm 0,53$ & $12,7 \pm 0,48$ \\
\hline
\end{tabular}

Примітка: вірогідність різниці між контрольною та дослідними групами: ${ }^{*}-\mathrm{P}<0,05,{ }^{* *}-\mathrm{P}<0,01$

Кількість еритроцитів у крові молодняку третьої та четвертої дослідних груп мала тенденцію до зниження порівняно 3 другою дослідною групою, проте була вищою на 2,5 та 1,7 \% відповідно, ніж у птиці контрольної групи.

Гусенята третьої та четвертої дослідних груп відрізнялися від своїх ровесників із контрольної групи й за вмістом гемоглобіну в крові. Різниця на користь дослідних груп за цим показником становила 8,6 та 2,4 \% відповідно.

Це своєю чергою позначилося на середньому вмісті гемоглобіну в одному еритроциті, який у птиці другої дослідної групи зріс на 2,4 \%, третьої - на 6,1 та четвертої - на 1,1 \% і досяг рівня 38,6 пг, 40,0 та 38,1 пг відповідно.

Щодо лейкоцитів, то у молодняку дослідних груп спостерігалася тенденція до підвищення їхньої кількості в крові відповідно до 24,12 Г/л, 24,16 та 24,37 Г/л. Порівняно 3 контрольною групою різниця становила $2,1 \%, 2,3$ та $3,2 \%$.

Збільшення кількості лейкоцитів у постнатальному онтогенезі, в межах фізіологічної норми, вказує на стимулюючий вплив добавок Селену на лейкопоетичну функцію кісткового мозку, лімфатичних вузлів та селезінки. Зміни кількості лейкоцитів мають позитивний характер, оскільки в кров надходить додаткова кількість зрілих клітин, які здатні виконувати захисні функції.

Подібна закономірність щодо впливу Селену на гематологічні показники крові відмічалася й іншими вченими при проведенні дослідів на різних видах i вікових групах сільськогосподарської птиці (Shevchenko et al., 2009; Jenginoeva et al., 2011; Fawzy et al., 2016; Sobolev et al., 2017). Водночас деякі вчені встановили, що напування курчат-бройлерів водою 3 добавками Селену не впливає на їхні гематологічні показники (Ponomarenko, 2007).

Одним із показників, який характеризує фізіологічний стан організму птиці, $є$ вміст білків у сироватці крові. Білки беруть участь у багатьох фізіологобіохімічних процесах в організмі. Аналіз умісту загального білка в сироватці крові хоча і не виявив вірогідних відмінностей між групами, проте його концентрація у гусенят дослідних груп була вищою на 0,71,9 г/л, або 1,4-3,8 \%, ніж у їх ровесників 3 контроль- ної групи. Підвищення рівня загального білка в сироватці крові молодняку птиці дослідних груп може свідчити про позитивний вплив селену обмін та синтез білків у їхньому організмі.

Багатьма дослідниками також встановлено, що згодовування птиці комбікорму, який збагачений Селеном, підвищує рівень загального білка в сироватці крові (Shackih, 2009; Gružauskas, 2014). Проте у науковій літературі $\epsilon$ повідомлення, що введення Селену в комбікорми не впливає на рівень білка в сироватці крові птиці (Liu, 2020).

Уведення Селену до складу комбікормів для гусенят справило позитивний вплив на природну неспецифічну резистентність організму птиці і, як наслідок, на іiї стійкість до дії несприятливих факторів зовнішнього середовища. На це вказує не тільки вміст загального білка, а й рівень імуноглобулінів у сироватці крові. Так, на кінець періоду вирощування концентрація імуноглобулінів у сироватці крові молодняку другої дослідної групи визначалася на більш високому рівні (13,6 г/л). Різниця стосовно контрольної групи, у якої цей показник дорівнював 12,4 г/л, становила 9,7 \%. Аналогічні показники у третій та четвертій дослідних групах також виявилися вищими, ніж у контрольній групі - на 4,8 та 3,2 \% відповідно.

Тенденцію до підвищення природної неспецифічної резистентності організму i, як наслідок, кращої збереженість птиці дослідних груп у науковому досліді можна пояснити активацією селеном гуморального ланцюга імунітету, внаслідок чого посилюються вироблення та надходження в кров не тільки еритроцитів та лейкоцитів, а й імуноглобулінів.

Результати наших досліджень цілком узгоджуються 3 висновками багатьох учених, котрі вважають, що активація селеном гуморального ланцюга імунітету пов'язана з посиленням біосинтезу імуноглобулінів i, як наслідок, підвищенням їхньої концентрації у сироватці крові, особливо класів $\operatorname{IgA}, \operatorname{IgG}, \operatorname{IgM}$ (Surai \& Taylor-Pickard, 2008; Saad et al., 2009; Shabani et al., 2019).

Беручи до уваги антиоксидантні властивості Селену та його зв'язок із системою глутатіону, ми дослідили рівень останнього в крові піддослідної птиці. Будучи носієм активної групи тіолів у вигляді залишку цистеїну, глутатіон бере участь у трьох лініях за- 
хисту клітин організму від деструктивної дії різних окиснювачів із чотирьох i, таким чином, займає центральне місце у функціонуванні антиоксидантної системи організму. Рівень глутатіону та ферментів, зв'язаних із його метаболізмом, визначає адаптаційну здатність організму до несприятливих факторів (активації окисних процесів) та його можливість ефективно здійснювати детоксикацію ліпофільних і гідрофільних ксенобіотиків, що надзвичайно важливо для забезпечення функціональної активності клітин. Він також $є$ важливим фактором, що сприяє формуванню антиокислювального статусу шлунково-кишкового тракту (Lushchak, 2012).

Глутатіон буває у двох формах: відновленій (трипептид) та окисненій (дисульфід). Завдяки окисненню дисульфіду в трипептид i, навпаки, у клітині створюється окисно-відновна рівновага. Виявлено взаємозв'язок між умістом глутатіону в крові та деякими господарсько-корисними ознаками птиці. Так, вміст загального i, особливо, відновленого глутатіону позитивно корелює 3 показниками живої маси птиці, а окисненого - негативно.

Подібна закономірність спостерігалась у птиці дослідних груп, для якої характерні вищі показники швидкості росту та живої маси. Так, під впливом добавок Селену в крові гусенят дослідних груп підвищився вміст загального та відновленого глутатіону. Порівняно 3 контрольною групою різниця у другій дослідній групі становила відповідно 5,1 (Р < 0,05) та $6,9 \%(\mathrm{P}<0,05)$, у третій $-6,8(\mathrm{P}<0,01)$ та $8,4 \%(\mathrm{P}<$ $0,05)$, у четвертій $-6,5(\mathrm{P}<0,05)$ та $4,7 \%$. Підвищення концентрації загального глутатіону в другій та третій дослідних групах відбулося за рахунок його відновленої форми, а в четвертій - відновленої та окисненої форм. Свідченням цього є рівень окисненого глутатіону, який в крові молодняку другої та третьої дослідних груп знизився - на 2,7 та 0,9 \% відповідно, а четвертої дослідної групи, навпаки, зріс на 15,4 \% порівняно з контрольною групою, у якої цей показник становив 11,0 мг/100 мл.

Відомо, що свої захисні та відновлювальні властивості глутатіон виявляє в усіх органах і системах, у тому числі й кровотворних, і вони прямо залежать від його концентрації. Напевне, ще й цим можна пояснити підвищення кількості формених елементів, вмісту гемоглобіну, загального білка та імуноглобулінів у крові гусенят дослідних груп.

\section{Висновки}

На основі вивчення гематологічних, імунологічних i біохімічних показників крові можна зробити висновок, що гемоцитопоез, окисно-відновні процеси, клітинні та гуморальні фактори захисту, а також неферментативна ланка антиоксидантної системи захисту краще виражені в організмі гусенят, які упродовж періоду вирощування одержували комбікорми, збагачені Селеном, і відрізнялися від своїх ровесників із контрольної групи вищими показниками продуктивності та життєздатності. Добавка Селену в комбікорми у дозі 0,3 мг/кг справила найбільш суттєвий пози- тивний вплив на морфологічні та біохімічні показники крові гусенят.

\section{References}

Ahangari, Y. J., Parizadian, B., \& Zamani, M. (2013). The impact of organic selenium supplementation on rooster semen quality in liquid condition. Poultry Science, 1(1), 23-31. doi: 10.22069/PSJ.2013.1469.

Bjorklund, G. (2015). Selenium as an antidote in the treatment of mercury intoxication. Biometals, 28(4), 605-614. doi: 10.1007/s10534-015-9857-5.

Chena, K., Fanga, J., Penga, X., Cuia, H., Chena, J., Wanga, F., Chena, Z., Zuoa, Z., Denga, J., Laia, W., \& Zhoub, Y. (2014). Effect of selenium supplementation on aflatoxin B1-induced histopathological lesions and apoptosis in bursa of Fabricius in broilers. Food and Chemical Toxicology, 74, 91-97. doi: 10.1016/j.fct.2014.09.003.

Fawzy, M. M., El-Sadawi, H. A., El-Dien, M. H., \& Mohamed, W. A. M. (2016). Hematological and biochemical performance of poultry following zinc oxide and sodium selenite supplementation as food additives. Annals of Clinical Pathology, 4(4), 1076.

Graupner, A., Eide, D. M., Instanes, C., Andersen, J. M., Brede, D. A., Dertinger, S. D., Lind, O. C., BrandtKjelsen, A., Bjerke, H., Salbu, B.,Oughton, D., Brunborg, G., \& Olsen, A. K. (2016). Gamma radiation at a human relevant low dose rate is genotoxic in mice. Scientific Reports, 6, 32977. doi: 10.1038/srep32977.

Gružauskas, R., Barštys, T., Racevičiūtè-Stupelienè, A., Kliševičiūtė, V., Buckiūnienè, V., \& Bliznikas, S. (2014). The effect of sodium selenite, selenium methionine and vitamin e on productivity, digestive processes and physiologic condition of broiler chickens. Veterinarija ir Zootechni, 65(87), 22-29. https://vetzoo.1smuni.lt/data/vols/2014/65/pdf/gruzaus kas.pdf.

Jenginoeva, T., Gadzaonov, R., \& Omarov, R. (2011). Selenosoderzhashij preparat Univetsell. Pticevodstvo, 4, 47-48 (in Russian).

Liu, H., Yu, Q., Fang, C., Chen, S., Tang, X., Ajuwon, K.M., \& Fang, R. (2020). Effect of selenium source and level on performance, egg quality, egg selenium content, and serum biochemical parameters in laying hens. Foods, 9(1), 68. doi: 10.3390/foods9010068.

Lushchak, V. I. (2012). Glutathione homeostasis and functions: potential targets for medical interventions. Journal of amino acids, 736837. doi: 10.1155/2012/736837.

Mottet, A., \& Tempio, G. (2017). Global poultry production: current state and future outlook and challenges. World's Poultry Science Journal, 73(2), 245-256. doi: 10.1017/S0043933917000071.

Ponomarenko, Ju. (2007). Selen i jod v racionah brojlerov Pticevodstvo, 4, 38-39 (in Russian).

Ramoutar, R. R., \& Brumaghim, J. L. (2010). Antioxidant and anticancer properties and mechanisms of inorganic selenium, oxo-sulfur, and oxo-selenium compounds. Cell Biochem Biophys, 58, 1-23. doi: $10.1007 / \mathrm{s} 12013-010-9088-\mathrm{x}$. 
Rocha, João B. T., Piccoli, B. C., \& Oliveira, C. S. (2017). Oliveirab Biological and chemical interest in selenium: a brief historical account. The Free Internet Journal for Organic Chemistry, part ii, 457-491. doi: 10.3998/ark.5550190.p009.784.

Saad, M. B., Gertner, L. R., Bona, T. D., \& Santin, E. (2009). Selenium influence in the poultry immune response - review. Recent Pat Food Nutrition \& Agriculture, 1(3), 243-247. doi: 10.2174/2212798410 901030243.

Shabani, R., Fakhraei, J., Yarahmadi, H. M., \& Seidavi, A. (2019). Effect of different sources of selenium on performance and characteristics of immune system of broiler chickens. Revista Brasileira de Zootecnia, 48, e20180256. doi: 10.1590/rbz4820180256.

Shackih, E. V. (2009). Biohimicheskij sostav krovi brojlerov pri ispol'zovanii razlichnyh form selena. Agrarnyj vestnik Urala, 3, 76-78 (in Russian).

Shevchenko, A. I., Nozdrin, G. A., \& Smolovskaja, O. V. (2009). Morfologicheskie pokazateli krovi gusej pri skarmlivanii im probiotika "Vetom 1.1", selena i ih kompleksa. Sibirskij vestnik sel'skohozjajstvennoj nauki, 4, 50-54 (in Russian).

Shirsat, S., Kadam, A., Mane, R. S., Jadhav, V. V., Zate, M. K., Naushad, Kwang, M., \& Kim, K. H. (2016). Protective role of biogenic selenium nanoparticles in immunological and oxidative stress generated by enrofloxacin in broiler chicken. Dalton Transaction, 45(21), 8845-8853. doi: 10.1039/c6dt00120c.

Shojadoost, B., Kulkarni, R. R., Yitbarek, A., Laursen, A., Taha-Abdelaziz, K., Alkie, T. N., Barjesteh, N., Quinteiro-Filho, W. M, Smith, T. K., \& Sharif, S. (2019). Dietary selenium supplementation enhances antiviral immunity in chickens challenged with low pathogenic avian influenza virus subtype H9N2. Vet Immunol Immunopathol, 207, 62-68. doi: 10.1016/j.vetimm.2018.12.002.

Sobolev, A. I., Gutyj, B. V., Petryshak, O. I., Golodjuk, I. P., Petryshak, R. A., \& Naumyuk, O. S. (2017). Morphological and biochemical blood indicators of ducklings, which are raised for the purpose of meat with the different level of selenium in feeding-stuffs.
Scientific Messenger LNUVMBT named after S.Z. Gzhytskyj, 19(74), 57-62. doi: 10.15421/nvlvet7413.

Sobolev, O., Gutyj, B., Petryshak, R., Pivtorak, J, Kovalskyi, Y., Naumyuk, A., Petryshak, O., Semchuk, I., Mateusz, V., Shcherbatyy, A., \& Semeniv, B. (2018). Biological role of selenium in the organism of animals and humans. Ukrainian Journal of Ecology, 8(1), 654-665. doi: 10.15421/2017_263.

Sobolev, O. I. (2010). Rekomendacii' shhodo vykorystannja selenu v godivli m'jasnogo molodnjaku sil's'kogospodars'koi' ptyci. "PP Kozhura V.V.", Bila Cerkva (in Ukrainian).

Surai, P. F. (2018). Selenium in poultry nutrition and health. Wageningen Academic Publishers, Hardback. doi: 10.3920/978-90-8686-865-0.

Surai, P. F., \& Taylor-Pickard, J. A. (2008). Current advancer in selenium research and applications. Hardback. doi: 10.3920/978-90-8686-642-7.

Tsuneda, P., Tsuneda, B., Hatamoto-Zervoudakis, L., Zervoudakis, J., Marinho, W., Junior, M., Araújo, E., Motheo, T., \& Silva, L. (2019). Dietary selenium supplementation and sperm quality in brangus bulls semen. Ciencia Animal Brasileira, 20, e-48586. doi: 10.1590/1089-6891v20e-48586.

Vijayakumar, E. P., \& Damodaran, K. (2015). Economics of poultry farming: a critical review. International Journal of Economic and Business Review, 3(8), 6367.

Wahyono, N. D., \& Utami, M. M. D. (2018). A Review of the Poultry Meat Production Industry for Food Safety in Indonesia. Journal of Physics: Conference Series, 953(1), 012125. doi: 10.1088/17426596/953/1/012125.

Wallenberg, M., Misra, S., Wasik, A.M., Marzano, C., Björnstedt, M., Gandin, V., \& Fernandesa, A. P. (2014). Selenium induces a multi-targeted cell death process in addition to ROS formation. Journal of Cellular and Molecular Medicine, 18(4), 671-684. doi: $10.1111 / \mathrm{jcmm} .12214$.

Zeng, H., Cao, J. J., \& Combs, G. F. (2013). Selenium in bone health: roles in antioxidant protection and cell proliferation. Nutrients, 5(1), 97-110. doi: 10.3390/nu5010097. 